\title{
EFFECTS OF HIGH-INTENSITY INSPIRATORY MUSCLE TRAINING IN RUGBY PLAYERS
}

\author{
EFEITOS DO TREINAMENTO DE ALTA INTENSIDADE DA MUSCULATURA INSPIRATÓRIA \\ NOS ATLETAS DERUGBY

\begin{abstract}
EFECTOS DEL ENTRENAMIENTO DE ALTA INTENSIDAD DE LA MUSCULATURA INSPIRATORIA EN ATLETASDERUGBY
\end{abstract}

Original Article

ARtigo Original

Artículo Original

\author{
Adauto de Oliveira Nunes Júnior ${ }^{1,2}$ \\ (Physiotherapist) \\ Marina Andrade Donzeli ${ }^{3}$ \\ (Physiotherapist) \\ Suraya Gomes Novais Shimano ${ }^{4}$ \\ (Physiotherapist) \\ Nuno Miguel Lopes de Oliveira ${ }^{4,5}$ \\ (Physiotherapist) \\ Gualberto Ruas ${ }^{4}$ \\ (Physiotherapist) \\ DernivalBertoncello $0^{4,6}$ \\ (Physiotherapist)
}

1. Universidade Federal doTriângulo Mineiro (UFTM),

Department of Physiotherapy,

Uberaba, MG, Brazil.

2. Universidade de São Paulo (USP),

Department of Physiotherapy,

Ribeirão Preto, SP, Brazil.

3. Universidade Federal do

Triângulo Mineiro (UFTM), Programa

de Pós-Graduação em Educação

Física, Uberaba, MG, Brazil.

4. Universidade Federal do

Triângulo Mineiro (UFTM),

Department of Applied

Physiotherapy, Uberaba, MG, Brazil.

5. Universidade Estadual

Paulista (UNESP), Department of

Physiotherapy, Presidente Prudente,

SP, Brazil.

6. Universidade Federal de São

Carlos (UFSCar), Department of

Physiotherapy, São Carlos, SP, Brazil.

\section{Correspondence:}

Rua Atibaia, 55, Jardim Paulista, Ribeirão Preto, SP, Brazil. 14090-140. adauto_fox@hotmail.com

\begin{abstract}
Introduction: Rugby is a sport characterized by high and low intensity motor action. Therefore, the respiratory muscles need adequate work to maintain sustained effective breathing. Objective: To analyze the effects of high-intensity inspiratory muscle training (IMT) in amateur rugby players from the city of Uberaba, Minas Gerais, Brazil. Methods: This is a clinical study in which 20 amateur players underwent a pulmonary function test, respiratory muscle strength and physical capacity assessment. The participants were divided into two groups: 10 volunteers in the IMT group (G1) and 10 in the control group (G2). All the assessments were carried out before and after 12 weeks of IMT. Results: No significant changes were observed in the pulmonary function test. However, maximal voluntary ventilation, maximal inspiratory pressure, maximal expiratory pressure and distance increased significantly after IMT. Conclusion: IMT had beneficial effects on amateur rugby players. Level of evidence l; Therapeutic studies - Investigation of treatment results.
\end{abstract}

Keywords: Rugby; Physical endurance; Resistance training; Athletes.

\section{RESUMO}

Introdução: O rugby é um esporte caracterizado por ações motoras com alta e baixa intensidade. Desse modo, os músculos respiratórios necessitam do trabalho adequado para manter a respiração efetiva de modo sustentado. Objetivo: Analisar os efeitos do treinamento da musculatura inspiratória (TMI) de alta intensidade nos atletas amadores de rugby da cidade de Uberaba, Minas Gerais, Brasil. Métodos: Este estudo caracteriza-se por ser um estudo do tipo clínico, em que 20 jogadores amadores foram submetidos à avaliação da prova de função pulmonar, força muscular respiratória e capacidade física, divididos em dois grupos: 10 voluntários no grupo TMI (G1) e 10 no grupo controle (G2). Todas as avaliações foram realizadas no período de pré e pós-12 semanas de TMI. Resultados: Observou-se que a prova de função pulmonar não apresentou nenhuma alteração significante. No entanto, a ventilação voluntária máxima, a pressão inspiratória máxima, a pressão expiratória máxima e a distância percorrida apresentaram aumentos significativos após o TMI. Conclusão: O TMI proporcionou efeitos benéficos nos jogadores amadores de rugby. Nível de evidência l; Estudos terapêuticos - Investigação dos resultados do tratamento.

Descritores: Rugby; Resistência física; Treinamento de resistência; Atletas.

\section{RESUMEN}

Introducción: El rugby es un deporte caracterizado por acciones motoras con alta y baja intensidad. Deeste modo, los músculos respiratorios necesitan un adecuado trabajo para mantener la respiración efectiva de modo sostenido. Objetivo: Analizar los efectos del entrenamiento de la musculatura inspiratoria (EMI) de alta intensidad en los atletas de rugby de la ciudad de Uberaba, Minas Gerais, Brasil. Métodos: Este estudio se caracteriza por ser un estudio de tipo clínico, en el que 20 jugadores aficionados fueron sometidos a evaluación de la función pulmonar, fuerza muscular respiratoria y la capacidad física, divididos en dos grupos: 10 voluntarios en el grupo EMI (G1) y 10 en el grupo control (G2). Todas las evaluaciones se realizaron antes y después del período de 12 semanas de EMI. Resultados: Se observó que la prueba de función pulmonar no mostró ninguna alteración significativa. Sin embargo, la ventilación voluntaria máxima, la presión inspiratoria máxima, la presión espiratoria máxima y distancia recorrida presentaron aumentos significativos después del EMI. Conclusión: El EMI proporcionó efectos benéficos en los jugadores aficionados de rugby. Nivel de Evidencia l; Estudios terapéuticos - Investigación de los resultados del tratamiento.

Descriptores: Rugby; Resistencia física; Entrenamiento de resistencia; Atletas. 


\section{INTRODUCTION}

With the advancement of sports technology within rugby, the games have become increasingly competitive and consequently havelead players to different levels of intense and exhaustive training, thus contributing to the increase in the number of injuries, diaphragmatic muscle fatigue, including dyspnea and decrease of physical capacity. Rugby is a sport distinguished by its short duration and high intensity motor action, alternating periods of longer duration and lower intensity motor actions. These characteristics require from players to perform optimally on biomotor skills such as aerobic endurance, anaerobic power, movement speed, agility and explosive strength. ${ }^{1}$

During sports activities, athletes perform a hyperventilation to maintain the oxygen supply in the cell and for the purpose reducing the effectiveness of exercise at the anaerobic threshold. ${ }^{2}$ In hence, the respiratory muscles need adequate work to maintain effective sustaining respiration. ${ }^{3}$

Some studies argue that respiratory muscle fatigue can impair exercise effectiveness. They demonstrate that the inspiratory muscle training (IMT) slows the respiratory muscle fatigue, lactate concentration and metaboreflex, which can increase the strength and respiratory muscle strength, thereby improving performance in thesport. ${ }^{4-8}$

The feature responsible for the athlete's performance limitation is the so-called metaboreflex, in which metabolites accumulation during fatiguing muscle exercise promotes an increase in muscle sympathetic nerve activity and consequently peripheral vasoconstriction.9-11

The IMT with linear pressure loading equipment has been considered a potential modifying agent of strength and inspiratory muscle strength, as well as attenuatingthe metabolic accumulation during inspiratory muscle work, resulting in the decrease of diaphragmatic muscle fatigue, dyspnea and increase of physical performance. ${ }^{12-15}$

Therefore, the inspiratory muscle training with high pressure loads on rugby players need be elucidated. Thus, a study that contributes to the effectiveness of the IMT of high intensity in the improvement and quality of the sports performance in rugby athletes is justified. Therefore, the objective of this study was to analyze the effects of high intensity IMT on amateur rugby athletes.

\section{MATERIALS AND METHODS}

This study makes use ofdescriptive and analytical methodology with simple randomization and cause-and-effect analysis among the investigated variables. The randomization was performed with recomposition in sealed and opaque plastic envelope for each volunteer in order to define the training group. The study was approved by the Research Ethics Committee of the FederalUniversity of TriânguloMineiro under protocol no. 2398. All players were informed and guided regarding the procedures to which they would be submitted and signed a Free and Informed Consent Term according to the Resolution No. 466/12 of the National Health Council.

Twenty amateur rugby players participated in this study. They all carried out two hours of weekly training, three times a week. They were all teammates from the Taurus university rugby team.

The trainings were held on Tuesdays, Thursdays and Saturdays. The matches were held every other Sunday. The training was specific and kept the same sequence: warm up, technical training, physical training and cool down.

The warm-up began with a light jogging for five minutes, and dynamic stretching of the major muscle groups. The technical training was the simulation of specific moves applied togames to improve its fundamentals, such as passing, blocking, feinting and collective strategicmoves. The physical training was done with exercises of intensity and agility, like jumps, 50-100-metersprints and fast shiftingwith obstacles. Regarding the cooldown, it ended with the stretching of the main muscle groups required in the sports modality, like: quadriceps, hamstrings, sural triceps, shoulder, biceps and triceps.

Players were divided into two groups: high intensity IMT group (G1) and control group (G2).

The inclusion criteria for the study were: healthy men; over 18; intermediate level of playing; at least six months of training; having participated in two official matches. The excluded ones: smokers and / or stimulating or anabolic steroid drug users.

G1 and G2 were submitted to the following evaluations: pulmonary function test, respiratory muscle strength (FMR) and physical capacity. The evaluations were performed before and after 12-week period of ITM. The evaluations occurred on four separate non-consecutive days.

The forced vital capacity (FVC), the forced expiratory volume in the first second $\left(F E V_{1}\right)$, the relation between $F E V_{1} / F V C$ and maximal voluntary ventilation (MVV) were measured using the Master Scope spirometer from Jäeger (Wuerzburg, Germany ) properly calibrated. At least three acceptable curves of each of the maneuvers were considered and the spirometric values were expressed as a percentage of the predicted value for the Brazilian population. ${ }^{16}$

\section{FMR - maximal inspiratory pressure (MIP) and maximal expiratory pressure (MEP)}

MIP and MEP were performed through a properly calibrated Ger-Aranalogue manovacuometer (São Paulo, Brazil), scaled at -300 to $+300 \mathrm{cmH}_{2} \mathrm{O}$. A maximum of ten consecutive measurements were performed, at least three reproducible measures, with less than $10 \%$ of difference between them. ${ }^{17}$

The YoYo Test was performed following the protocol consisting of a first sound signal, where the players left the starting position, traveling 20 meters to the end point. This coincided with a second signal and they should return to the starting position with a third signal, totaling 40 meters for each stage and kept jogging for 10 seconds to recover and then repeated the path. Each level of intensity consisted of a number of stages which were reached at the same speed. Thus, when reaching following the level, the time between each signal was reduced, forcing them to increase the running speed to remain in the test. Those who could not keep up with sound signals twice in a row were eliminated from the test and the distance traveled (DT) at which they stopped was noted. The tests were done in the morning, between eight and nine o'clock, on a natural grass soccer field. In addition, everyonehad their oxygen pulse saturation, heart rate, lower limb fatigue sensation, dyspnea and systemic blood pressure monitoredbefore and after the tests. ${ }^{18}$

Players received the IMT program within three weekly sessions, for 12 consecutive weeks totaling 36 sessions, all supervised by a physiotherapist and a physical education professional.

The G1 IMT protocol consisted of:

- 10 minutes of trunk muscles, upper and lower limbs stretching;

- 10-minute warm-up with a series of 10 repetitionsand one-minute intervals. The players were asked to perform a full and vigorous inspiration, through the linear pressure load equipment Breather Plus IMTPower ${ }^{\circledR}$, (Technologies Ltd, Birmingham, UK). The heating chamber was considered a pressure level prior to the ITM load;

- IMT was performed after 10 minutes of rest after warm-up, consisting of a series of 30 repetitions using $80 \%$ of MIP, with increasing pressure levels always from the fourth training session.To calculate the training load, the pressure level closest to $80 \%$ of the load in $\mathrm{cmH}_{2} \mathrm{O}$ was collected.

The G2 IMT protocol consisted of:

- The control group (G2) performed the same protocol as the ITM group, but with no additional resistive load. 


\section{Statistical analysis}

Statistical software InStat ${ }^{\circledR}$ version 3.05 (GraphPad Software Inc., San Diego, CA, USA) was used to analyze the results. The normality of the data was verified by applying of the Shapiro Wilk test, which determined that all the variables of the study had a normal distribution. Values were expressed as mean and standard deviation. The tstudent tests were performed, paired and unpaired, and the significance level was set at $p \leq 0.05$.

\section{RESULTS}

A total of 25 players were evaluated for possible participation in the study. However, five were excluded because they did not complete the evaluations and because they are anabolic steroid users. Of the total, 20 players were randomized and 10 were included in G1 (six backs and four forwards) and 10 in G2 (six backs and four forwards), as shown in Figure 1.

Table 1 shows the variables of the groups studied. There were no significant differences between them. G1 and G2 players did not use bronchodilators nor oral corticosteroids.

No significant difference was observed between the number of sessions and the duration. There were 36 sessions, happening three times a week for 12 weeks and the average time of 30 minutes. In addition, all patients tolerated IMT without presenting any exacerbation.

Demographic, anthropometric characteristics and pulmonary function (FVC, FEV1 $_{\text {1 }}$ and ${ }_{\mathrm{FEV} 1} / \mathrm{FVC}$ ) showed no significant change from the baseline compared to the final evaluation after the ITM groups. However, MV ( $p=0.03)$, MIP ( $p=0.04)$, MEP $(p=0.02)$ and SD $(p=0.04)$ had significant increases in $\mathrm{G} 1$ when compared to $\mathrm{G} 2$ Table 2), representing an improvement of $22 \%, 38 \%, 32 \%$ and $13 \%$ respectively.

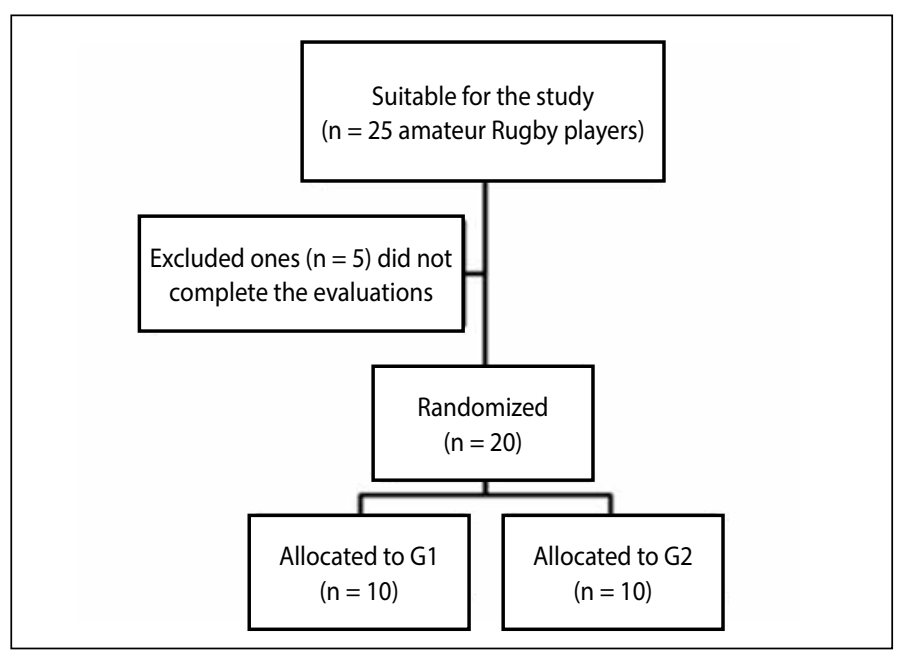

Figure 1. Flow diagram of the study participants' participation.

\section{DISCUSSION}

The main result of this study was the demonstration that the high intensity IMT for 12 weeks with loads of $80 \%$ provided important and significant and increases in MVV, MIP and PEmax and PD in amateur rugby players.

It can be noted that no matter how effective the cardiovascular system is in supplying adequate amounts of blood to tissues, physical capacity will be compromised if the respiratory system does not provide sufficient oxygen supply to satisfy the demands. When the arrival of the blood to respiratory muscles is decreased, it experiences fatigue and consequently causing lactic acid buildup. This situation causes a decrease in the strength and resistance of the respiratory muscles. ${ }^{19}$

Several studies have been carried out involving IMT in athletes, in an attempt to solve the factors described above and yet to improve
Table 1. Demographic, anthropometric and initial variables values assessed from G1 and G2.

\begin{tabular}{|c|c|c|}
\hline Variables & $\mathrm{G} 1(n=10)$ & $\mathrm{G} 2(n=10)$ \\
\hline \multicolumn{3}{|l|}{ Demographic and Anthropometric } \\
\hline Age years) & $22 \pm 4$ & $23 \pm 2$ \\
\hline Bodymass (kg) & $86 \pm 9$ & $87 \pm 3$ \\
\hline Height $(\mathrm{cm})$ & $179 \pm 5$ & $178 \pm 2$ \\
\hline Body Mass Index $\left(\mathrm{kg} / \mathrm{m}^{2}\right)$ & $26 \pm 1$ & $26 \pm 2$ \\
\hline Lean Muscle Mass (kg) & $50 \pm 2$ & $51 \pm 2$ \\
\hline Body Mass Index (MM / height²) & $15 \pm 1$ & $15 \pm 3$ \\
\hline \multicolumn{3}{|l|}{ Spirometry } \\
\hline FVC (\% prev) & $97 \pm 5$ & $98 \pm 3$ \\
\hline $\mathrm{FEV}_{1}(\%$ prev $)$ & $94 \pm 6$ & $94 \pm 13$ \\
\hline $\mathrm{FEV}_{1} / \mathrm{FVC}(\%)$ & $94 \pm 5$ & $93 \pm 2$ \\
\hline WM (\% prev) & $100 \pm 14$ & $102 \pm 13$ \\
\hline \multicolumn{3}{|l|}{ Respiratory muscle strength } \\
\hline $\mathrm{Mw}\left(\mathrm{cmH}_{2} \mathrm{O}\right)$ & $160 \pm 4$ & $157 \pm 20$ \\
\hline $\mathrm{Mw}\left(\mathrm{cmH}_{2} \mathrm{O}\right)$ & $151 \pm 44$ & $153 \pm 20$ \\
\hline \multicolumn{3}{|l|}{ YoYo Test } \\
\hline DP (meters) & $660 \pm 45$ & $645 \pm 26$ \\
\hline
\end{tabular}

Data are expressed as means and standard deviations; G1: group with high intensity IMT; G2: without IMT contro group; kg: kilogram; cm: centimeter; $\mathrm{kg} / \mathrm{m}^{2}$ : kg per square meter; MM: lean muscle mass; FVC: forced vital capacity; $\mathrm{FEV}_{1}$ : forced expiratory volume in the first second; $\mathrm{FEV}_{1} / \mathrm{FVC}$ : forced expiratory volume ratio in the first second and forced vital capacity; VVM: maximum voluntary ventilation; PImax: Maximum inspiratory pressure; $\mathrm{CmH}_{2} \mathrm{O}$ : centimeter of water; DP: distance traveled in YoYo Test. (Test $t$ Student unpaired, $\mathrm{p}<0.05$ ).

Table 2 .Comparisons of $\mathrm{G} 1$ and $\mathrm{G} 2$ pre and post IMT variables.

\begin{tabular}{c|c|c|c|c}
\hline Variables & GI & & G2 & \\
\hline & PRE & POST & PRE & POST \\
\hline Spirometry & & & & \\
\hline FVC (\% prev) & $97 \pm 5$ & $99 \pm 6$ & $98 \pm 3$ & $97 \pm 6$ \\
\hline $\mathrm{FEV}_{1}(\%$ prev) & $94 \pm 6$ & $94 \pm 5$ & $94 \pm 13$ & $95 \pm 18$ \\
\hline $\mathrm{FEV}_{1} / \mathrm{FVC}(\%)$ & $94 \pm 5$ & $93 \pm 3$ & $93 \pm 2$ & $93 \pm 3$ \\
\hline $\mathrm{WM}(\%$ prev) & $100 \pm 14$ & $122 \pm 26^{*}+$ & $102 \pm 13$ & $100 \pm 25$ \\
\hline Respiratory muscle strength & & & & \\
\hline $\mathrm{MW}\left(\mathrm{cmH}_{2} \mathrm{O}\right)$ & $160 \pm 4$ & $207 \pm 11^{*}+$ & $157 \pm 20$ & $155 \pm 10$ \\
\hline $\mathrm{MW}\left(\mathrm{cmH}_{2} \mathrm{O}\right)$ & $151 \pm 44$ & $200 \pm 10^{*}+$ & $153 \pm 20$ & $153 \pm 35$ \\
\hline YoYo Test & & & & \\
\hline $\mathrm{DP}$ (meters) & $660 \pm 45$ & $750 \pm 21^{*}+$ & $645 \pm 26$ & $642 \pm 21$ \\
\hline
\end{tabular}

Data are expressed as means and standard deviations; G1: group with high intensity IMT; G2: control group without IMT; FVC: forced vital capacity; FEV : forced expiratory volume in the first second; FEV / FVC: forced expiratory volume ratio in the first second and forced vital capacity; $\mathrm{VVM}$ : maximum voluntary ventilation; PImax: Maximum inspiratory pressure; $\mathrm{CmH}_{2} \mathrm{O}$ : centimeter of water; DP: distance traveled in YoYo Test. ( $\mathrm{St}$-test unpaired $\mathrm{t}$ student; $\uparrow \mathrm{p}$ $=0.05$ (Post $G 1$ vs. Post $G 2$ ), (s paired t test $t$ Student; $p=0.05 *$ (pre vs. post $G 1$ and $G 2$ ).

physical capacity. IMT has already been shown to be effective in soccer, basketball, cycling, swimming, running and other sports, so it was an important resource used to try to delay the onset of diaphragmatic muscle fatigue, positively reflecting the improvement in ventricular performance and physical ability. ${ }^{12,20-25}$

Athletes during training and competitions meet the demand for oxygen, ventilation and present increased cardiovascular function. ${ }^{12,26}$ However, with the IMT,the volumes and respiratory capacities are unchanged, confirming our study, in which there were no changes. This process requires respiratory muscles to shrink intensively and coordinately. ${ }^{27}$ However, doubts persist and controversies exist regarding the percentage to be adopted in the training load.

Studies have shown that IMT in athletes from different areas had positive effects on physical performance, respiratory muscle strength and MIP, though with a $50 \%$ training load. ${ }^{20,23,25,28}$ The load of $80 \%$ of the MIP adopted in this study is due to the fact that all the players did not report any discomfort. When the stimulus is adequate for the improvement of the strength (MIP) and resistance of the respiratory muscles (MVV), this allows the maximization of inthe physical capacity and intensity. ${ }^{29}$ 
In the present study, it is observed that the amateur players of rugby, presented a significant increase of $22 \%$ of VVM, $38 \%$ of MIP and $32 \%$ of MEP when compared to G2.

The functional consequence of such improvement may be observed by the 13\% increase in PD. These results support the hypothesis that the benefits of IMT at $80 \%$ of PI max attenuate the pressor response, reduce metabolic accumulation, muscle fatigue, and reduce lower blood flow in the lower limbs during induction of meta-reflexive activity.

The metaboreflex is an important limiting feature for the athlete's physical ability.Therefore, some studies evaluating IMT, indicate that training with inspiratory load decreases metaboreflex and the consequent peripheral muscle fatigue, influencing positively in the athlete's performance.,
But the efficiency of the high-intensity IMT with the Power Breather linear load resistor is not reported in the literature for amateur rugby players. Thus, it is suggested that the training protocol performed in this study has a positive effect for these players.

\section{CONCLUSION}

The high intensity IMT with linear pressure loading equipment provided beneficial effects in amateur rugby players, with significant increase in VVM, PImax, PEmax and DP.

All authors declare no potential conflict of interest related to this article.

AUTHORS' CONTRIBUTIONS: Each author made significant individual contributions to this manuscript. AONJ (0000-0003-1593-5346)*: project execution and data analysis; MAD (0000-0002-8986-079X): analysis of results, discussion and final analysis of the article; DB (0000-0002-4432-4651)*: revision of the experimental design and of the final data; GR (0000-0003-1802-9883)*: preparation and revision of the initial project; SGNS (0000-0002-9421-9227)* and NMLO (0000-0001-7295-7491)*: analysis and discussion of data. All authors contributed to the intellectual concept of the study and approved the final version of the manuscript. *ORCID (Open Researcher and Contributor ID).

\section{REFERENCES}

1. Bompa T, Claro F. Periodization in Rugby. UK: Meyer \& Meyer Sports; 2015.

2. Bernardi E, Melloni E, Mandolesi G, Uliari S, Grazzi G, Cogo A. Respiratory muscle endurance training improves breathing pattern in triathletes. Ann Sports Med Res. 2014;(1):1003.

3. Ovechkin AV, Sayenko DG, Ovechkina EN, Aslan SC, Pitts T, Folz RJ. Respiratory motor training and neuromuscular plasticity in patients with chronic obstructive pulmonary disease: a pilot study. Respir Physiol Neurobiol. 2016;229:59-64.

4. Verges S, Lenherr O, Haner AC, Schulz C, Spengler CM. Increased fatigue resistance of respiratory muscles during exercise after respiratory muscle endurance training. Am J Physiol Regul Integr Comp Physiol. 2007;292(3):R1246-53

5. Spengler CM, Roos M, Laube SM, Boutellier U. Decreased exercise blood lactate concentrations after respiratory endurance training in humans. EurJ Appl Physiol Occup Physio. 1999;79(4):299-305.

6. Callegaro CC, Ribeiro JP, Tan CO, Taylor JA. Attenuated inspiratory muscle metaboreflex in endurance-trained individuals. Respir Physiol Neurobiol. 2011;177(1):24-9.

7. Witt JD, Guenette JA, Rupert JL, McKenzie DC, Sheel AW. Inspiratory muscle training attenuates the human respiratory muscle metaboreflex. J Physiol. 2007;584(Pt3):1019-28.

8. Sales AT, Fregonezi GA, Ramsook AH, Guenette JA, Lima IN, Reid WD. Respiratory muscle endurance after training in athletes and non-athletes: a systematic review and meta-analysis. Phys Ther Sport. 2016;17:76-86.

9. Katayama K, Itoh Y, Saito M, Koike T, Ishida K. Sympathetic vasomotor outflow and blood pressure increase during exercise with expiratory resistance. Physiol Rep. 2015;3(5):e12421.

10. Corrêa AP, Antunes CF, Figueira FR, de Castro MA, Ribeiro JP, Schaan BD. Effect of acute inspiratory muscle exercise on blood flow of resting and exercising limbs and glucose levels in type 2 diabetes. PLoS One. 2015;10(3):e0121384.

11. Moreno AM, Castro RR, Silva BM, Villacorta H, Sant'Anna Junior M, Nóbrega AC. Intercostal and forearm muscle deoxygenation during respiratory fatigue in patients with heart failure: potential role of a respiratory muscle metaboreflex. Braz J Med Biol Res. 2014;47(11):972-6.

12. HajGhanbari B, Yamabayashi C, Buna TR, Coelho JD, Freedman KD, Morton TA, et al. Effects of respiratory muscle training on performance in athletes: a systematic review with meta-analyses. J Strength Cond Res. 2013;27(6):1643-63.

13. Yi SJ, Kim JS. The effects of respiratorymuscle strengthening exercise using a sling on the amount of respiration. J Phys Ther Sci. 2015;27(7):2121-4.

14. Kim J, Park JH, Yim J. Effects of respiratorymuscle and endurance training using an individualized training device on the pulmonary function and exercise capacity in stroke patients. Med Sci Monit. 2014;20:2543-9.
15. Croitoru A, Bogdan MA. Respiratorymuscle training in pulmonary rehabilitation. Pneumologia. 2013;62(3):166-71.

16. Pereira CC, Sociedade Brasileira de Pneumologia e Tisiologia. I Consenso Brasileiro sobre Espirometria. J Bras Pneumol. 1996;22(3):105-64.

17. Green M, Road J, Sieck GC, Similowski T. American Thoracic Society/European Respiratory Society. ATS/ ERS Statement on respiratory muscle testing: Tests of Respiratory Muscle Strength. Am J Respir Crit Care Med. 2002;166(4):528-42

18. Bangsbo J, Mohr M, Poulsen A, Perez-Gomez J, Krustrup P.Training and testing the elite athlete. J Exerc Sci Fit. 2006;4(1):1-14.

19. Wilmore JH, Costill DL. Fisiologia do Esporte e do Exercício. 2.ed. São Paulo: Manole, 2001.

20. Nicks CR, Morgan DW, Fuller DK, Caputo JL. The influence of respiratory muscle training upon intermittent exercise performance. Int J Sports Med. 2009;30(1):16-21.

21. Goosey-Tolfrey V, Foden E, Perret C, Degens H. Effects of inspiratory muscle training on respiratory function and repetitive sprint performance in wheelchair basketball players. Br J Sports Med. 2010;44(9):665-8.

22. Gething AD, Williams M, Davies B. Inspiratory resistive loading improves cycling capacity: a placebo controlled trial. Br J Sports Med. 2004;38(6):730-6.

23. Romer LM, McConnell AK, Jones DA. Effects of inspiratory muscle training on time-trial performance in trained cyclists. J Sports Sci. 2002;20(7):547-62.

24. Wylegala JA, Pendergast DR, Gosselin LE, Warkander DE, Lundgren CE. Respiratory muscle training improves swimming endurance in divers. Eur J Appl Physiol. 2007;99(4):393-404.

25. Tong TK, Fu FH, Chung PK, Eston R, Lu K, Quach B, et al. The effect of inspiratory muscle training on high-intensity, intermittent running performance to exhaustion. Appl Physiol Nutr Metab. 2008:33(4):671-81.

26. Guenette JA, Martens AM, Lee AL, Tyler GD, Richards JC, Foster GE, et al. Variable effects of respiratory muscle training on cycle exercise performance in men and women. Appl Physiol Nutr Metab. 2006;31(2):159-66.

27. Forbes S, Game A, Syrotuik D, Jones R, Bell GJ. The effect of inspiratory and expiratory respiratory muscle training in rowers. Res Sports Med. 2011;19(4):217-30.

28. Kilding AE, Brown S, McConnell AK. Inspiratory muscle training improves 100 and $200 \mathrm{~m}$ swimming performance. Eur J Appl Physiol. 2010;108(3):505-11.

29. Weiner P, Magadle R, Beckerman M, Weiner M, Berar-Yanay N. Maintenance of inspiratory muscle training in COPD patients: one year follow-up. Eur Respir J. 2004;23(1):61-5. 